\title{
4. 教育システムの将来
}

\author{
坂 元 昂 ${ }^{\dagger}$
}

\section{1. 生涯学習とニューメディア}

\section{1 高度情報化社会と生涯学習}

わたしたちは今, 高度情報化社会にむかって進んで いる. 技術の開発やそれにともなう社会生活の変化 は，まことに急激である．有名な McHaleの図によ ると, 物理学上の発見と応用の間隔は, この数十年の 間に急激に短くなっている ${ }^{1)}$. 例えば，写真では 112 年であったのに, 電話で 56 年, ラジオ 35 年, 真空 管 33 年, X 線管 18 年, レーダ 15 年, テレビジョン 12 年, トランジスタ 3 年, マイクロエレクトロニク ス関係 1.5 年と, 20 世紀後半に入って急激に短くな ってきている. Solomon と Wardによるテレコミュ ニケーションの革新の図を見ても, モールス信号以来, 電話, 同軸ケーブル, マイクロ波, サテライト, $\mathrm{T}-4$ ファイバと桁上りの情報量の增大を示している2.

まさしく社会は急速に変り, 新しい製品がどんどん 開発されてきている.わたしたちは，このような社会 に対応し, 自らその社会を創り出す一員として生活し ていかなければならない。それには, 大学までの学校 教育の中で着実に学習してくることが必要であるが, それだけでは不充分である。学校で身につけた技術や 知識がすぐに古くなってしまって, 社会の変化に対応 できないからである。

働きながら, 生活しながら, 絶えず学習をし続ける ことが必要となる。いわゆる生涯学習である。

昭和 56 年には, 中央教育審議会が「生涯教育につ いて」答申を出し，生涯教育についての考え方を，人 間が一生涯にわたって教育を受けるところまで範囲を 拡大した ${ }^{3)}$.さらに, 昭和 61 年の臨時教育審議会の 第 2 次答申では, 生涯学習体系への移行が強調され, それは昭和 62 年の最終答申までひきつがれる4).

生涯学習は, 情報社会においては二重の意味で大切

†東京工業大学 総合理工学研究科システム科学専攻

“4. Future of Educational Systems" by Takashi Sakamoto (Graduate School, Tokyo Institute of Technology, Tokyo)
である、ひとつは情報化社会そのものにおける情報革 新やその影響について, わたしたちは, 絶えず新しく 学んでいかねばならないことである。いわば教育内容 としての情報化である. 単に情報に関する新しい知識 を身につけていくにとどまらない。いろいろな情報技 術を使いこなし, 活用する能力も身につけておかねば ならない. 次は, 高度情報化社会に向って続々と生み 出されてくる新しい情報技術を道具として使い, 働き ながら, 家庭に居ながら, わたしたちは一生学習を続 けることである。いわば教育方法としての情報化であ る.

臨時教育審議会は, 事柄の重要性をわきまえ, 昭和 59 年から昭和 62 年にかけて 4 回にわたる答申をした が，その中に情報化の問題を一貫して重視してきた。 情報化に関する委員会を, 部会をこえて作り, 最終答 申では「教育が直面している最も重要な課題は国際化 ならびに情報化への対応である」と断言した ${ }^{5)}$.

そして,

（1）学校をはじめ様々な教育機関において情報活 用能力の育成に本格的に取り組む.

（2）指導の個別化, 指導形態の柔軟化を可能に し, 双方向の意思疎通, とくに学習者からの発 信機能を強化させるとともに, 学習の時間的・ 空間的制約を緩和させる技術的可能性を有して いる情報手段の潜在力を, すべての教育機関の 活性化のために最大限に活用する.

（3）情報化の進展が与える身体的, 精神的, 文化 的影響に関する教育的見地からの分析・評価を 進め, 情報化の影の部分を補うための教育を拡 充するとともに，教育環境の人間化を支援する ような形で情報手段を教育の場に組み込む. ような対応を進めていくことが重要であるという．

これは, 第 2 次答申の情報化に対応する教育の三原 則（1) 社会の情報化に備えた教育を本格的に展開す る，(2)すべての教育機関の活性化のために情報手段 の潜在力を活用する, (3) 情報化の影を補い, 教育環 
境の人間化に光をあてる）を拡張したものである.こ れからの新しい教育システムを設計する際に配慮すべ きことといえる。

\section{2 ニューメディアとネットワーク化}

これと並行して, 昭和 62 年に, 社会教育審議会教 育メディア分科会も「生涯学習とニューメディア」と いう報告を出した ${ }^{6)}$.

生涯学習を支える教育情報システムを, 学校教育と 社会教育の両面で, しかも施設内, 施設間, 地域, 全 国規模の範囲で，それぞれ，ニューメディアを中心に 形成しようという提言である.

テレトピアの文部省版とも考えられる．

ニューメディアを,

(1) 単体系(物流系, パッケージ系) : ビデオディ スク,コンパクトディスク，コンピュータ.

（2）有線 (通信) 系: CATV, ビデオテックス, コンピュータ通信, その他の通信系メディア, ISDN.

（3）無線（放送）系：テレビ音声多重放送, テレ ビ文字放送, テレビ静止画放送，その他の多重 放送, 高精細度テレビ放送, 衛星放送, 衛星通 信.

に 3 分し, これらを組み合わせた教育システムで, 学 習のための原資料や 2 次情報を提供しょうとする提言 である。

全国的な教育情報システムのネットワークは，今日 まだできていないが，地域的には事例が見られる。千 葉県旭地区教育情報センターは, 小学校の社会科の資 料をホストのコンピュータのデータベースから, 小学 校に置かれたコンピュータに公衆電話回線で送ってい る. 6 年生の教材は, 教室で, 子供たちが直接教材提 示を受けることもできる.また, 尼崎市総合教育セン ターも, 小学校 1 年生から 6 年生までの計算問題や誤 答例を, ホストコンピュータから小学校に置かれたコ ンピュータに教師の要求に従って送っている.

キャプテン・システムにも僅かではあるが教材は入 っているし，VRSにも教材が入っている，CATVで 教材を送っている地域もある. ファクシミリやコンピ ユー夕通信で学習指導を行っている例もある。

ただ今日, これらは特定の地域に限られ, またシス テムとしても独立して運営されているにすぎない. 将 来は, これら各種の教育システムが統合されてネット ワークを形成することになるものと予想される.

この時, 学校や社会教育機関は, 情報技術を完備し た，いわゆるインテリジェントスクールになることだ ろう。

\section{3 内外の行政的対応}

諸外国においても，情報化への対応は国家的な課题 となっている。

アメリカでは, 1983 年「危機に立つ国家」という教 育改革案が連邦政府に提出された ${ }^{77}$. 日本, 西ドイ ツ, 韓国に対する経済発展の遅れは，まさに国家危㭕 であり，その原因となっている教育を革新しなくては ならないという提言であった。

さらに 1984 年には, 連邦政府から教育工学特別委 員会が委嘱され，この危機を具体的に解消する方法の 検討が始まった. 1986 年の報告のまとめでは「アメリ 力教育を変革する一一国家危機を解消する」という夕 イトルの提言がなされた ${ }^{8)}$. 要点は, 各州にハイテク 学校を作り, 有志の教師と子供たちを集め徹底的に情 報技術を駆使した教育を行い，国家危機を救う道を見 つけようとするものであった.

もつとも，この試みは必ずしも正式の法案などのう ら打ちをうることができなかったが, コンピュータの 学校への普及は $90 \%$ 越している。イギリス, フラ ンス, カナダなども, 国家的計画, 全州的計画の下に コンピュータを中心とする情報教育に費用と人材を投 じ，新しい時代の教育にとりくみはじめている．これ らの国々では, ほとんどの学校にコンピュータが導入 され, ワープロ, 作図, 作表, 教科の学習などに活用 されはじめている。

日本でも, 昭和 62 年 12 月に公表された教育課程審 議会の「教育課程の基準の改善について」の答申では, 教育のあらゆる面でコンピュータがとり入れられるべ きであるとの基本方針を明らかにした ${ }^{9)}$.これからの 学習指導要領はこれを基に作成されるので, 今後の日 本の学校における情報化は, 一挙に進展するものと予 想される。

さらに, 通産省も学校教育へのコンピュータ導入, ワープロ導入に力を入れ，情報処理技術者養成のため の CAI を開発し, 労働省も職業訓練へのコンピュー 夕利用を検討し，郵政省もネットワークエンジニアの ための人材育成支援システムの検討をはじめ, 民間て も企業内 CAI システムに関心が集まり，という状況 が生まれるに及んで, 日本社会における教育の情報化 も動きはじめたように思われる ${ }^{10) ~ 12) . ~}$

\section{2. コミュニケーションシステム}

\section{1 教育におけるコミュニケーション}

教育過程は， 3 方向のコミュニケーションから成り 立っている。

ひとつは，教授者から学習者への働きかけである. 
兑明, 解説, 図解, 模範演技などの情報提示と発問, 筫問, 指示, 指名, 誘導などの行動制御が含まれ, 学 習者は，これらの働きかけを受けとる。

次は，学習者の反応とそれについての教授者の診 断, 評価の働きである. 学習者の応答, 作文, 発言, 寅算，演技，挙動などを，教授者は，観察，ノート調 べなどで捉え, 目標と照合して評価を下す.

もうひとつは, 教授者から学習者のフィードバック である. 正誤, 正解, 要約などを提示したり, ほめた り，叱ったり，うなづいたり，ほほえんだりする。

この 3 方向のコミュニケーションが, 教授者と学習 者, ときには学習者どうしの間で成り立つときが教育 である.コミュニケーションメディアは,この 3 方向 カコミュニケーションの間に入って, 教授者から学習 者へ, あるいは学習者から教授者への情報の伝達を拡 大代行する，例えば，テレビは教授者の情報伝達の働 きを拡大する。しかし，それは診断したり学習者にフ イードバックを与えたりしない.教授者の機能の部分 的拡大を行うにすぎない。

\section{2 メディアミックス}

ぞのようなメディアも，教授者や学習者の機能を拡 大するが，それは部分的にである。その意味でメディ アは，教授者の様々な機能を拡大するために組み合わ せて用いられることが望ましい。

図 1 はメディアの構造である.印刷物, 模型, 実 物，スライド，シート，フィルム，テープ，コンパク トディスク, ビデオテープ, ビデオディスク, フロッ ピーディスク, 放送番組, テレテキスト, 静止画デー

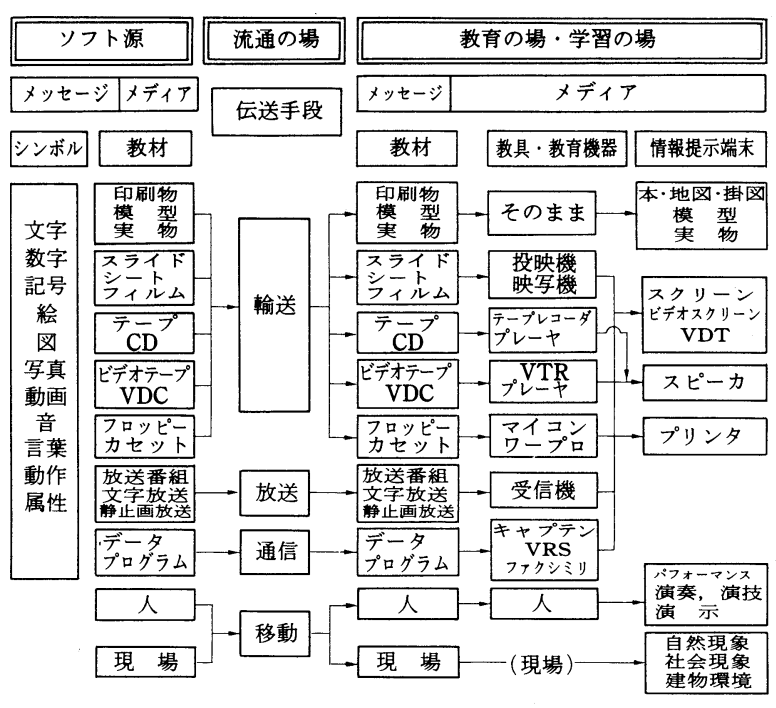

図 1 メディアの分類
夕，人間など，いろいろな組み合わせで情報を伝達す ることができる．

しかし学習者の立場に立つと, 学習時に端末で触れ ることになるのは, 印刷教材, 映像教材, 音声教材, 人物の演示, 演技, 自然, 社会, 環境である.そこ で, 少なくともこれだけの種類のメディアの組み合わ せを教育システムでは考慮しておく必要がある。それ には教授者が，メディアを使わない教育過程の設計を し, その中でひとつひとつ最適なメディアを導入し て, 教授者の機能を拡大していく方策をとるとよい.

教授者と学習者が問答し, 教授者は情報を $\mathrm{OHP}$, ビデオ, コンピュータなどで一斉指導的に提示し, 学 習者の反応をノートや発言やコンピュータで採取し, 学習者に自らフィードバックを与えたり, 印刷物で回 答を示したりする。

よく考えられているように, テレビだけ, コンピュ ータだけで学習が行われることの方が, むしろ珍らし いと考えられる。まったくの個人学習の場合を除く と, たいてい学習仲間や教師がついており, 教科書, ガイドブックなどがあるからである。このように，組 み合わせた上で活用されるメディアのうち，これから の教育システムで注目を浴びてくると思われるのは,

(1) 単体系では, コンピュー夕, ビデオディス ク, CDV, CDI などである。

（2）有線系では, コンピュー夕通信, 映像通信, CATVなどである。

（3）無線系では, 文字放送, 静止画放送などであ る.

（4）単体系としては, コンピュータが何より も大きな将来性をもっている。

現在, 日本では年間 200 万台のマイクロコンピ ュータが生産され, 広く職場や学校や家庭に普及 しはじめた。

これらは教授者の教授活動を支援するための道 具として, また, 学習者の学習活動を支援するた めの道具として, 幅広く活用されはじめている. もちろん, 教授活動や学習活動の研究のための情 報処理の道具として, また, 学校, 学級経営など を支援する道具としてもっとよく使われている． 今日の日本の学校では, コンピュータが学習指導 の道具として使われている割合は, 小学校で 55 $\%$, 中学校で $39 \%$, 高校で $51 \%$ であ, 学校学 級経営の道具として使われている割合はそれぞれ 84\%, 95\%, 95\%である ${ }^{13)}$.

学習指導の道具としては, 教授者の教材提示を 助けるため, 学習者への指示のため, 評価問題の 
提示のため, 個別指導のため用いられる.

従来は, CAI としてドリルやテュートリアル形式 の個別学習用システムが, コンピュータの教育利用で あると誤解されがちであった．たしかに，ひとりひと りの学習者が身近に指導者をうることができない場 で, たとえば家庭学習, 職場での自己研修, 学校で も, 個別学習, 複式学級, 自習などの事態で用いられ ることがあり，それなりの効果をあげてきた。しか し, 教育のための道具は, 知育の本質, たとえば人間 と人間との心の触れ合い, 自主的, 創造的問題解決な どの場における学習を助けるために用いられてほし い.

そこでコンピュータは, 次のようなさまざまな利用 をされる。自然現象や社会現象のシミュレーションを 教室で提示し, その時, 現象についての仮説や解釈を

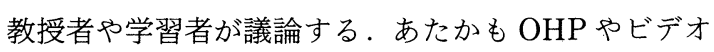
が普通の教室で使われるのと似た状況であるが，その 時の議論の成り行きで, 変数を自由に変えて入力でき るという点で, コンピュー夕は有効である.データべ 一スから, 社会科の資料, 図表などを必要に応じてと り出して示すことも可能である。このような方式は, 一斉指導に長じた日本の教授者にとって, また, 同時 に学習者にとっても, コンピュータを導入したという 異和感が少ない.

さらに好ましいのは, 現在のコンピュータの不充分 な画像を補う役目を, 映像機器に受けもたせることで
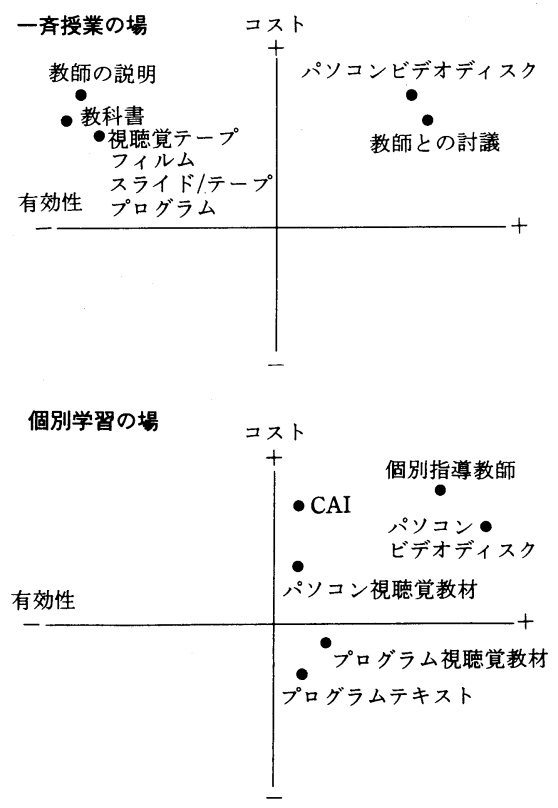

図 2 パソコンビデオディスクの効果
ある.ビデオテープ, ビデオディスク，CDV，ビテ オフロッピーの類である.これら画像のデータベース から静止画あるいは動画情報をとり出し, コンピュー タで教授過程を制御することによって, 映像機器の特 色とコンピュータの特色を統合することができる．テ メリカやイギリスでは, この種のシステムに関心が集 まっている。

Young の分析によると図2のように，この種のシ ステムがコストと効果において優れていることが示ざ れている ${ }^{14)}$.この種のシステムは, 教授者の教材提示 のみでなく, 個別指導型の CAIにも有効である. ンピュータだけでも, 図表, 評価問題の生成, 提示 さらには評価が, 学習者の学習程度に合わせてでき 複数の台数があれば, 同時に多数の学習者に, 個別に 対応する指導をするための教授者の手助けとなる.

しかし最近では, 学習者の学習活動を助ける道具と してコンピュータが使われる点に関心が集まってい る.自然や社会現象のシミュレーションや数式のグシ フ表現などを, 学習者からのパラメータの変化に応し て実現するものである，学習者は，パラメータをさま ざまに変え，その変化をディスプレイ上に見て，現鱼 やグラフに潜む法則性を発見学習する。データベース から自由に資料や資料の所在情報をとり出し，それる を用いて問題解決をする。ささらに, 作文, 作図, 作 表, 計測, 制御などの道具としてコンピュータを用い る.これらのすべての使い方は, コンピュータが教援 者の教授機能を代行して学習者を教えるものではな い. 学習者が主体的に自ら学ぶのを支援する教育シス テムなのである.

\section{$2.3 \mathrm{CAI}$ の今後}

いわゆるCAIに関しても，次第に知的になってき たが，まだ不充分であり，これからの開発が期待され る.キーボード入力やマウスによる入力だけでなく 手書き文字や図形, カメラからの画像入力ならびに それらの処理認識の技術が確立してくるにしたが二 て, 自然の状態に近い形での学習が可能になる.

マイクロコンピュータでも, 手書き文字式や多角形 図形などの認識ができ, 人間の顔のパターンや表情の 認識もできるようになっているので, 将来の教育シス テムでは, 手書き入力, 表情の診断, さらには音声認 識によって入力がなされ，えられた情報は，人工知能 的に処理され, 入力に応じたフィードバックがかけき れることになろう.

たとえば, 分数の計算を手書きで解いていく過程を ひとつひとつコンピュータが認識して，そのたびに道 切なヒントや解説を加えることができるからである. 
ただ現状では，コンピュータにソフトや操作上の互 渙性がなく, 学校や家庭での普及に大きな障害となっ ている。これを克服しょうと，学校用ワープロの標準 化ならびに教育用パソコンの標準化の計画が進んでい る。諸外国でも，イギリスの $\mathrm{BBC}$ マシン, フランス つナノレゾ, スウェーデンの Compis, デンマークの ピコリーニ, カナダのオンタリオ州の Icon/LEXICON など教育用標準機種をもち, 購入補助金などで 普及促進をはかっているところが見られる。しかし， 一概にうまくいっているということはできない.

\section{3. 遠隔教育システム}

放送系や有線系のメディアを用いて教育するシステ ムが，遠隔教育システムである.

最も普及しているのが放送による遠隔教育である． 簡単にできるのは, 電話による個別相談, 個別学習指 導, FAXの利用などである。

日本でも遠隔教育を主とする教育システムがいくつ か運用されている。最も大規模なのが放送大学であ り，学校における教育番組の利用である。電話線を通 して静止画映像を送ったりSSTVを用いて企業内教 育を行う事例もあるし、コンピュー夕通信によって学 習指導をする例も見られる。

しかし，日本人は一般に講義を聞く，授業を受ける などの受動的な学習の仕方を好むので, せっかく放送 講義を受講した後, FAX やコンピュータで質問の場 を設けても，ほとんど反応がない。したがって，コミ ユニケーション手段を含んだ教育システムを構築して も, 普通はなかなか利用してもらえないことになろ う.もっとも, マニアの間ではコンピュー夕通信によ る情報のやりとりは盛んなので, 次第に遠隔コミュニ ケーションシステムが教育にも有効に利用されること になるかもしれない.

\section{4. 教育における画像の効用と限界}

教育には，さまざまな画像が利用される。それらは 主として, 抽象的な概念や原則を具体化するのに有効 である。また，それらは具体的な現実や自然の複雑な 事態を図解を通して理解し易くする。

すなわち，画像は抽象の世界と現実の世界を仲立ち して, 演繹と帰納を助ける働きをすると考えられる。 しかし，画像の世界はあくまでも虚構の世界であっ て, 原則としては画像を学習するだけでは, 学習が終
ったことにはならない. 自然現象の理解が画像によっ て助けられたなら, 次には, それを実験や観察で検証 する必要がある。逆に, 自然や社会現象に働く法則性 が画像によって浮きぼりされるならば，それをさらに 抽象化して公式や言語の水準で明確な記述がなされね ばならない。

ただ,これらは科学の世界の話なので, 芸術の世界 の話は別である．画像による芸術は，CG などを典型 として立派に成立しうるからである。

このような画像情報の特徵を生かしつつ, これから の教育システムは, 伝統的な諸メディアと組み合せて 総合的なシステムとして開発, 利用されることになる だろう。

(昭和 63 年 2 月 23 日受付)

\section{[参 考 文 献]}

1) J. McHale: "World Facts and Trends", Collier Books, New York (1972)

2) R. J. Solomon and J. Ward: "The Sequence of Inventions in Telecommunications, $1840-2000$, Adapted from James Martin: Future Developments in Telecommunications, 1976", Annenberg School of Communications (1980)

3）中央教育審議会：“生涯教育について”, 文部省（1981）

4）臨時教育審議会：“教育改革に関する第二次答申”, 総理府 (1986)

5）臨時教育審議会：“教育改革に関する第四次答申（最終答 申)” (1987)

6）社会教育審議会：“生涯学習とニューメディア”, 文部省 (1987)

7) National Commission on Excellence in Education: "A Nation at Risk", US Government Printing Office, Washington, D. C. (1983)

8) National Task Force on Educational Technology: "Transforming American Education: Reducing the Risk to the Nation" Tech. Trends, 31, 4, pp. 10-24, 35 (1986)

9）教育課程審議会: “幼稚園, 小学校, 中学校及び高等学校の教 育課程の基準の改善について (答申)” 文部省 (1987)

10）通商産業省機械情報産業局：“2000 年のソフトウエア人材”, コンピュータエージ社 (1987)

11）日本デー夕通信協会：“人材育成支援システムの調查研究に 関する報告書”（1987）

12）日本能率協会：“企業内に打けるCAIの現状について” (1987)

13）日本教育工学振興会：“新教育機器教育方法開発研究報告 書” (1986)

14) J. I. Young: "Videodisc Simulation Tommorow's Technology Today", Computers in Schools, 1, 2, pp. 47-57 (1984)

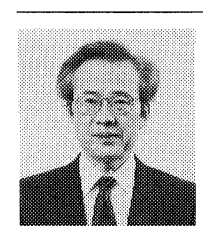

圾芫 筑 昭和 30 年, 東京大学文・心 理学部卒業. 東京工業大学助手, 助教授を経 て, 現在, 同教授. 教育工学, 教育心理学, 学習, 思考, マスコミニケーションなどの研 究に従事. コンピュータ教育開発センター理 事. 日本教育工学振興会理事. 大学入試セン 夕運営協議員. 放送教育開発センタ一運営協 議員. 文学博士. 